\section{South African academy in search of funds and a role}

Pretoria. After a long period of gestation, South Africa's new national academy, embracing both the natural sciences and humanities, was formally launched by President Nelson Mandela last month. The academy now faces the task of raising funds for activities - and deciding what role it will play in national debates on science, technology and education policy.

The new body, the Academy of Science of South Africa, will be based in Pretoria, and has the support of the three existing academies: the predominantly Englishspeaking Royal Society of South Africa, the Afrikaans-speaking Suid-Afrikaanse Akademie vir Wetenskap en Kuns and the Science and Engineering Academy of South Africa (SEASA).

But the new body is not an amalgamation of these academies. The two latter institutions will continue to focus on their own sectional interests, the first being concerned primarily with promoting the use of Afrikaans as a language, and the second with fostering science and engineering in black communities.

In terms of its stated aims, the main potential overlap is with the Royal Society of South Africa. The president of the latter organization, George Ellis, says that the society is reserving judgement about its future until the new academy has defined its role more clearly.

The new academy differs from the Royal Society of South Africa in that it embraces the humanities as well as the sciences. The society is also perceived by some observers as being regionally based (in Cape Town) and having an excessively narrow base, as its members and fellows are mainly Englishspeaking whites.

The president of the new academy, Khotso Mokhele, a microbiologist who is the new head of the Foundation for Research Development, is keen that its role should be that of an "activist", promoting not a tea and cookie society," says Mokhele. "The academy needs to make its mark in determining and implementing policy."

Reflecting this fact, the 96 founder members are made up not only of scholars who have made outstanding contributions to research, but also senior civil servants and university and research council administrators perceived to be in a position to promote the academy's objectives. In this sense the body differs from most academies in other countries.

At the same time, there are some glaring omissions in its membership, particularly in the humanities, including the social historians Charles van Onselen and Colin Bundy scientific thought in a broad sense. "This is and the author and critic John Coetzee. These result from the initial selection process, which was controlled by the three old academies, each of which has a different vision of what an academy should be (see Nature 361, 198; 1993).

Furthermore, funding prospects remain uncertain. Mokhele says that the academy needs to attract a diversity of funding sources from both the government and private sectors in order to maintain its independence. He points out that in other countries, national academies derive their income from various sources, ranging from direct government grants through contract research to (in the case of Australia) the sale of textbooks. As yet, the government of national unity has promised no funding.

At the academy's first meeting last month, members discussed various possible interventions in the fields of education and health, to be considered by its first council. For example, it was felt that the academy might become involved in the debate on a new national health plan.

Curriculum reform in the primary and secondary sectors was also suggested, as well as the possible establishment of a national qualifications framework. A further proposal was that the academy should become involved in assessing the research performance of university departments, if the National Commission on Higher Education decides to include such measures as part of a new funding formula for universities.

Michael Cherry
UK Parliament gives approval to terms of chemical arms ban
London. Britain's ratification of the Chemical Weapons Convention passed its final hurdle last week when it was approved in a third reading by the House of Lords, and has now been signed into law.

Although the government has not accepted demands for the creation of a statutory advisory body, as it had been urged to do by those who are keen to see a source of independent advice (see Nature 379, 479; 1996), it has promised that a non-statutory advisory mechanism will be established in the near future.

The government has also pledged to publish details of a proposed appeals process for researchers who are denied a license to use particular chemicals. Furthermore, in response to the claim that many of those in the academic community engaged in chemical research are still unaware of the extent to which the convention may affect their activities, the government has said that it will take action to ensure that the new bill is publicized as widely as possible.

Full implementation of the convention will require its ratification by 65 member states. It is widely hoped that this number will be reached by the end of June, allowing the convention to come into force at the beginning of next year.

In the United States, the treaty has already been passed out of the committee stage of the Senate, and ratification is now seen as largely a formality, primarily awaiting a decision by Republican leaders to schedule a debate on the Senate floor.

\section{New laser is 'the best and brightest'}

London. Last week saw the

first pulses fired in the world's most powerful ultraviolet laser, Titania, situated at Britain's Rutherford Appleton Laboratory (RAL). Based on two decades of development of krypton flouride lasers at RAL, the new laser will be able to subject samples placed inside a target area (see right) to single pulses of up to 10 terawatts (10 $10^{12}$ watts).

Titania will be used for a range of research applications that include fundamental plasma physics, the development of X-ray lasers, and various aspects of inertial confinement fusion. It will replace RAL's Sprite laser, which had been operating as a central facility for researchers from both Britain and abroad since 1981.

Inaugurating the laser, Paul Williams,

\section{IMAGE UNAVAILABLE FOR COPYRIGHT REASONS}

chief executive of the Council for the Central Laboratory of the Research Councils - which is now responsible for RAL - said that the funding restrictions under which the RAL's laser facilities had been built up over the past 20 years meant that its development teams "have had to be clever where others have just used raw dollars." 